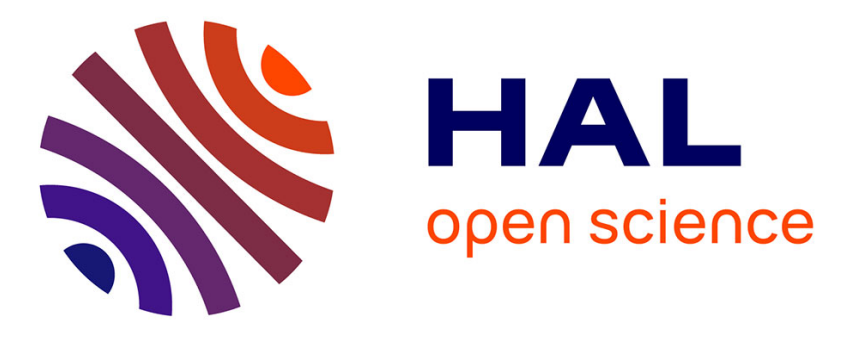

\title{
Actinopolyspora righensis sp. nov., a novel halophilic actinomycete isolated from Saharan soil in Algeria
}

Atika Meklat, Noureddine Bouras, Abdelghani Zitouni, Florence Mathieu, Ahmed Lebrihi, Peter Schumann, Cathrin Spröer, Hans-Peter Klenk, Nasserdine Sabaou

\section{To cite this version:}

Atika Meklat, Noureddine Bouras, Abdelghani Zitouni, Florence Mathieu, Ahmed Lebrihi, et al.. Actinopolyspora righensis sp. nov., a novel halophilic actinomycete isolated from Saharan soil in Algeria. Antonie van Leeuwenhoek, 2013, vol. 104 ( ${ }^{\circ}$ 3), pp. 301-307. 10.1007/s10482-013-9948-7 . hal-01177618

\section{HAL Id: hal-01177618 \\ https://hal.science/hal-01177618}

Submitted on 17 Jul 2015

HAL is a multi-disciplinary open access archive for the deposit and dissemination of scientific research documents, whether they are published or not. The documents may come from teaching and research institutions in France or abroad, or from public or private research centers.
L'archive ouverte pluridisciplinaire HAL, est destinée au dépôt et à la diffusion de documents scientifiques de niveau recherche, publiés ou non, émanant des établissements d'enseignement et de recherche français ou étrangers, des laboratoires publics ou privés. 


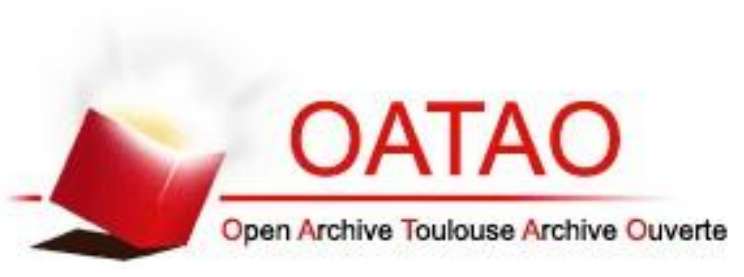

\section{Open Archive Toulouse Archive Ouverte (OATAO)}

OATAO is an open access repository that collects the work of Toulouse researchers and makes it freely available over the web where possible.

This is an author-deposited version published in: http://oatao.univ-toulouse.fr/ Eprints ID: 9759

DOI:10.1007/s10482-013-9948-7

Official URL: http://dx.doi.org/10.1007/s10482-013-9948-7

\section{To cite this version:}

Meklat, Atika and Bouras, Noureddine and Zitouni, Abdelghani and Mathieu, Florence and Lebrihi, Ahmed and Schumann, Peter and Spröer, Cathrin and Klenk, Hans-Peter and Sabaou, Nasserdine Actinopolyspora righensis sp. nov., a novel halophilic actinomycete isolated from Saharan soil in Algeria. (2013) Antonie van Leeuwenhoek, vol. 104 (n 3). pp. 301-307. ISSN 0003-6072

Any correspondence concerning this service should be sent to the repository administrator: staff-oatao@inp-toulouse.fr 


\title{
Actinopolyspora righensis sp. nov., a novel halophilic actinomycete isolated from Saharan soil in Algeria
}

\author{
Atika Meklat - Noureddine Bouras - Abdelghani Zitouni • \\ Florence Mathieu • Ahmed Lebrihi • Peter Schumann • \\ Cathrin Spröer · Hans-Peter Klenk • Nasserdine Sabaou
}

\begin{abstract}
A novel halophilic actinomycete strain, $\mathrm{H} 23^{\mathrm{T}}$, was isolated from a Saharan soil sample collected in Djamâa (Oued Righ region), El-Oued province, South Algeria. Strain $\mathrm{H} 23^{\mathrm{T}}$ was identified as a member of the genus Actinopolyspora by a polyphasic approach. Phylogenetic analysis showed that strain $\mathrm{H} 23^{\mathrm{T}}$ had $16 \mathrm{~S}$ rRNA gene sequence similarities ranging from $97.8 \%$ (Actinopolyspora xinjiangensis TRM $40136^{\mathrm{T}}$ ) to $94.8 \%$ (Actinopolyspora mortivallis DSM $44261^{\mathrm{T}}$ ). The strain grew optimally at $\mathrm{pH} 6.0-7.0,28-32{ }^{\circ} \mathrm{C}$ and in the presence of $15-25 \%(\mathrm{w} / \mathrm{v}) \mathrm{NaCl}$. The substrate mycelium was well developed and fragmented with age. The aerial mycelium produced long, straight or flexuous spore
\end{abstract}

A. Meklat $\cdot$ N. Bouras $\cdot$ A. Zitouni $\cdot$ N. Sabaou $(\bowtie)$ Laboratoire de Biologie des Systèmes Microbiens (LBSM), Ecole Normale Supérieure de Kouba, Alger, Algeria

e-mail: sabaou@yahoo.fr

\section{A. Meklat}

Département de Biologie, Faculté des Sciences Agronomiques, Vétérinaires et Biologiques, Université Saâd Dahleb, Blida, Algeria

\section{F. Mathieu · A. Lebrihi}

Laboratoire de Génie Chimique, UMR 5503 (CNRS/

INPT/UPS), INPT-ENSAT, Université de Toulouse,

1 Avenue de l'Agrobiopole, Auzeville Tolosane,

BP 32607, 31326 Castanet-Tolosan, France chains with non-motile, smooth-surfaced and rod-shaped spores. Strain $\mathrm{H} 23^{\mathrm{T}}$ had MK-10 $\left(\mathrm{H}_{4}\right)$ and MK-9 $\left(\mathrm{H}_{4}\right)$ as the predominant menaquinones. The whole microorganism hydrolysates mainly consisted of meso-diaminopimelic acid, galactose and arabinose. The diagnostic phospholipid detected was phosphatidylcholine. The major cellular fatty acids were anteiso- $\mathrm{C}_{17: 0}(37.4 \%)$, iso- $\mathrm{C}_{17: 0}(14.8 \%)$, iso- $\mathrm{C}_{15: 0}(14.2 \%)$, and iso- $\mathrm{C}_{16: 0}$ $(13.9 \%)$. The genotypic and phenotypic data show that the strain represents a novel species of the genus Actinopolyspora, for which the name Actinopolyspora righensis sp. nov. is proposed, with the type strain $\mathrm{H} 23^{\mathrm{T}}$ $\left(=\mathrm{DSM} 45501^{\mathrm{T}}=\right.$ CCUG $63368^{\mathrm{T}}=$ MTCC $\left.11562^{\mathrm{T}}\right)$.

Keywords Actinopolyspora righensis sp. nov. halophilic actinomycete - Algerian Sahara . Polyphasic taxonomy

\author{
A. Lebrihi \\ Université Moulay Ismail, Marjane 2, BP 298, Meknes, \\ Morocco \\ P. Schumann - C. Spröer · H.-P. Klenk \\ Leibniz Institute DSMZ-German Collection of \\ Microorganisms and Cell Cultures, Inhoffenstraße 7B, \\ 38124 Braunschweig, Germany
}




\section{Introduction}

The genus Actinopolyspora, which belongs to the family Actinopolysporaceae (Zhi et al. 2009), was originally established by Gochnauer et al. (1975) and the description was later emended by Tang et al. (2011). The genus currently contains 8 recognized species: Actinopolyspora halophila (Gochnauer et al. 1975), A. mortivallis (Yoshida et al. 1991), A. xinjiangensis (Guan et al. 2010), A. egyptensis (Hozzein and Goodfellow 2011), A. alba and A. erythraea (Tang et al. 2011), A. algeriensis (Meklat et al. 2012) and A. saharensis (Meklat et al. 2013). The two species 'A. egyptensis' and 'A. saharensis' were described recently and have not yet been validated.

The genus Actinopolyspora was shown to exhibit distinct chemotaxonomic characteristics: cell-wall chemotype IVA (meso-diaminopimelic acid, arabinose and galactose in whole-cell hydrolysates; Lechevalier and Lechevalier 1970), phospholipid type PIII (phosphatidylcholine as characteristic phospholipid; Lechevalier et al. 1977), MK-9 $\left(\mathrm{H}_{4}\right)$ and MK-10 $\left(\mathrm{H}_{4}\right)$, MK-9 $\left(\mathrm{H}_{4}\right)$ and MK-9 $\left(\mathrm{H}_{2}\right)$ or MK-6 as the predominant menaquinones, iso- $\mathrm{C}_{16: 0}$ and anteiso- $\mathrm{C}_{17: 0}$ as the major fatty acids and absence of mycolic acids (Gochnauer et al. 1989; Guan et al. 2010; Tang et al. 2011). During an investigation of the soil actinobacterial community in the Sahara desert of Algeria, an Actinopolysporalike strain was isolated. The aim of the present study was to determine the taxonomic position of this strain using polyphasic taxonomic approach.

\section{Materials and methods}

\section{Strain and culture conditions}

Strain $\mathrm{H} 23^{\mathrm{T}}$ was isolated from moderately saline soil (electrical conductivity $=2.3 \mathrm{mS} \mathrm{cm} \mathrm{cm}^{-1}$ ) of Oued Righ region (El-Oued) during an investigation of actinobacteria diversity in Saharan soils (Meklat et al. 2011). Serially diluted sample was plated on complex medium (CM) agar (Chun et al. 2000) supplemented with $20 \%$ (w/v) $\mathrm{NaCl}$ and incubated for 5 weeks at $30{ }^{\circ} \mathrm{C}$.

After primary isolation and purification, the isolate was preserved both on slants of $\mathrm{CM}$ agar at $4{ }^{\circ} \mathrm{C}$ and as $20 \%(\mathrm{v} / \mathrm{v})$ glycerol suspensions at $-20{ }^{\circ} \mathrm{C}$. Strain $\mathrm{H} 23^{\mathrm{T}}$ was deposited in the German Collection of
Microorganisms and Cell Cultures as strain DSM $45501^{\mathrm{T}}$, in the Culture Collection, University of Göteborg as strain CCUG $63368^{\mathrm{T}}$, and in the Microbial Type Culture Collection as strain MTCC $11562^{\mathrm{T}}$.

\section{Phenotypic characterization}

Cultural characteristics of the new isolated strain were determined after 3 weeks incubation at $30{ }^{\circ} \mathrm{C}$ on the International Streptomyces Project media (Shirling and Gottlieb 1966), CM agar (Chun et al. 2000) and nutrient agar (Waksman 1961). The ISCC-NBS colour name charts (Kelly and Judd 1976) were used to determine colony colours. Morphological characteristics were observed under light microscopy (B1, Motic) and scanning electron microscopy (Hitachi, S450) using cultures grown on $\mathrm{CM}$ agar at $30{ }^{\circ} \mathrm{C}$ for 4 weeks. Temperature range $\left(10-45^{\circ} \mathrm{C}\right), \mathrm{pH}$ range (5.0-9.0) and $\mathrm{NaCl}(0-35 \%$, w/v) tolerance for growth were determined on nutrient agar after incubating for 21 days at $30^{\circ} \mathrm{C}$. Utilization of carbohydrates, milk coagulation and peptonization, and decarboxylation of organic acids were evaluated using the method of Gordon et al. (1974). Degradation of other organic compounds was studied using protocol as described by Goodfellow (1971). Lysozyme sensitivity, methyl red and Voges-Proskauer tests, $\mathrm{H}_{2} \mathrm{~S}$ production and reduction of nitrate were determined according to the methods of Gordon and Barnett (1977) and Marchal et al. (1987), respectively.

\section{Chemotaxonomy}

Biomass for chemotaxonomy studies was obtained by cultivating the cell in shake flasks $\left(250 \mathrm{rpm}, 30^{\circ} \mathrm{C}\right.$, 10 days) using $\mathrm{CM}$ broth containing $15 \% \mathrm{NaCl}$ (w/v). Analysis of cell-wall amino acids and sugars in wholecell hydrolysates were carried out according to the methods described by Becker et al. (1964) and Lechevalier and Lechevalier (1970). Phospholipids were extracted, examined and identified by using the procedure developed by Minnikin et al. (1977). The cellular fatty acid composition was determined as described by Sasser (1990) using the microbial identification system (MIDI). Cellular menaquinones were extracted and purified as described by Minnikin et al. (1984) and were analyzed by HPLC (Kroppenstedt 1982, 1985). Analysis of mycolic acids was performed using the method of Minnikin et al. (1980). 
Phylogenetic analyses

Extraction of chromosomal DNA of $\mathrm{H} 23^{\mathrm{T}}$ strain was carried out as described by Liu et al. (2000). Amplification of the 16S rRNA gene by PCR and the sequencing of the purified PCR products were performed as described previously by Rainey et al. (1996). The resulting 16S rRNA gene sequence was compared with sequences obtained from public databases to determine the most closely related species using EzTaxon-e server (http://eztaxon-e.ezbiocloud.net/; Kim et al. 2012). Multiple alignments were performed using the CLUSTAL W program (Larkin et al. 2007). Phylogenetic trees were constructed using the neighbour-joining (Saitou and Nei 1987) with Jukes and Cantor (1969) model, maximum-likelihood (Felsenstein 1981) with Kimura 2-parameter (Kimura 1980) model and maximum-parsimony (Fitch 1977) methods. Bootstrap analysis was performed with 1,000 replicates (Felsenstein 1985) to validate the tree topology of the neighbour-joining method.

\section{Results and discussion}

Strain $\mathrm{H} 23^{\mathrm{T}}$ showed good growth on nutrient agar and CM agar media, while no growth was observed on ISP2 and ISP4 media. Strain formed irregularly branched substrate mycelia with yellowish colour on $\mathrm{CM}$ and nutrient agar. White aerial mycelium was observed on CM agar and nutrient agar media. Straight or flexuous chains of fragmented rod-shaped spores of aerial mycelium were observed (Fig. 1). The surface of spores was smooth. No diffusible pigments were produced on the tested media. Strain $\mathrm{H} 23^{\mathrm{T}}$ had morphological properties typical of members of the genus Actinopolyspora. It could grow at $20-40{ }^{\circ} \mathrm{C}, \mathrm{pH}$ 5.0-8.0 and $10-30 \% \mathrm{NaCl}$ with optimal $\mathrm{NaCl}$ concentration for growth at $15-25 \%(\mathrm{w} / \mathrm{v})$. The optimal temperature and $\mathrm{pH}$ for growth were $28-32{ }^{\circ} \mathrm{C}$ and 6.0-7.0, respectively. Detailed results of the physiological and biochemical analyses are given in the species description and in Table 1 .

The chemotaxonomic characteristics of strain $\mathrm{H} 23^{\mathrm{T}}$ supported its classification as a member of the genus Actinopolyspora. The meso-diaminopimelic acid was detected in its cell wall and the whole cell hydrolysates contained arabinose, galactose and small amount of

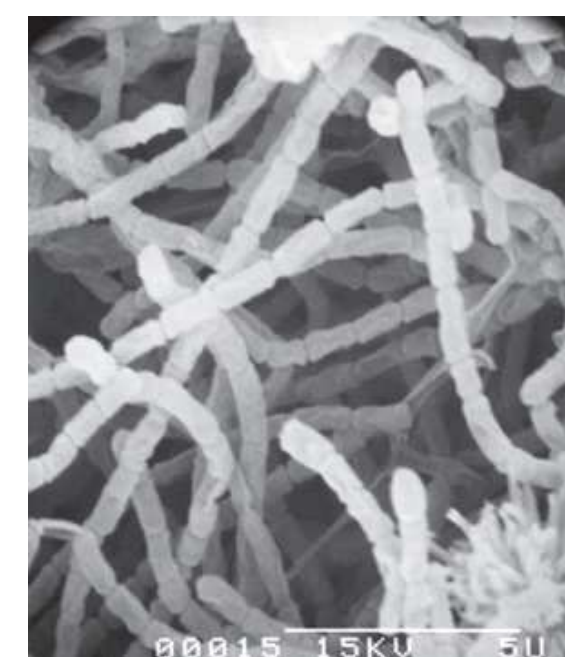

Fig. 1 Scanning electron micrograph of strain $\mathrm{H} 23^{\mathrm{T}}$ grown on complex medium agar containing $15 \%(w / v) ~ N a C l$ for 4 weeks at $30^{\circ} \mathrm{C}$. Bar $5 \mu \mathrm{m}$

ribose. Mycolic acids were not detected. The phospholipid profile contained diphosphatidylglycerol, phosphatidylcholine, phosphatidylinositol phosphatidylethanolamine, three unknown glycophospholipids and three unknown phospholipids (Fig. S1). The menaquinones detected were MK-10 (H4) (51.2\%), MK-9 (H4) (26.4\%), and minor amounts of MK-9 (5.2\%), MK-10 $\left(\mathrm{H}_{6}\right)(5.0 \%)$, MK-9 $\left(\mathrm{H}_{6}\right)(2.4 \%)$, MK-10 $\left(\mathrm{H}_{2}\right)(1.6 \%)$, MK-9 $\left(\mathrm{H}_{2}\right)(1.7 \%)$ and MK-10 $\left(\mathrm{H}_{8}\right)(0.7 \%)$ were also detected. The fatty acids profile was composed as follows: anteiso- $\mathrm{C}_{17: 0}$ (37.4\%), iso-C $\mathrm{C}_{17: 0}(14.8 \%)$, iso- $\mathrm{C}_{15: 0}(14.2 \%)$, iso$\mathrm{C}_{16: 0}(13.9 \%)$, cis $9-\mathrm{C}_{17: 1}(8.8 \%)$ and anteiso- $\mathrm{C}_{15: 0}$ (4.5\%).

Phylogenetic analysis based on 16S rRNA gene sequences (Fig. 2 and Fig. S2) revealed that strain $\mathrm{H} 23^{\mathrm{T}}$ belonged to the genus Actinopolyspora; levels of similarity between strain $\mathrm{H} 23^{\mathrm{T}}$ and the type strains of recognized Actinopolyspora species ranged from 94.8 to $97.8 \%$. Strain $\mathrm{H} 23^{\mathrm{T}}$ was related most closely to $A$. xinjiangensis TRM $40136^{\mathrm{T}}(97.8 \%)$, A. erythraea DSM $45583^{\mathrm{T}}(97.7 \%)$ and A. alba DSM $45004^{\mathrm{T}}$ $(97.5 \%)$. DNA-DNA relatedness experiments were not carried out between strain $\mathrm{H} 23^{\mathrm{T}}$ and its closest phylogenetic neighbours as the type strains of several Actinopolyspora species share 16S rRNA gene similarities within the range of $97.6-98.8 \%$, but have levels of DNA-DNA relatedness well below the $70 \%$ cut-off point recommended by Wayne et al. (1987) for the recognition of genomic species. For example, the 
Table 1 Differential physiologic and chemotaxonomic characteristics of strain $\mathrm{H} 23^{\mathrm{T}}$ and its closest relative recognized species of the genus Actinopolyspora

\begin{tabular}{|c|c|c|c|c|}
\hline \multirow[t]{2}{*}{ Characteristics } & \multicolumn{4}{|c|}{ Type strains } \\
\hline & 1 & 2 & 3 & 4 \\
\hline \multicolumn{5}{|l|}{ Utilization of } \\
\hline Fructose & + & + & - & - \\
\hline Galactose & + & + & + & - \\
\hline Lactose & + & ND & - & + \\
\hline Maltose & + & - & + & + \\
\hline Mannitol & - & - & - & + \\
\hline Mannose & + & - & + & + \\
\hline Xylose & + & + & + & - \\
\hline \multicolumn{5}{|l|}{ Decomposition of } \\
\hline Casein & + & ND & + & - \\
\hline Starch & - & - & + & + \\
\hline Tween 80 & + & + & + & - \\
\hline $\mathrm{NaCl}$ range $(\%, w / v)$ & $10-30$ & $8-25$ & $10-25$ & $10-25$ \\
\hline $\mathrm{NaCl}$ optimum $(\%, w / v)$ & $15-25$ & $10-15$ & $15-20$ & $15-20$ \\
\hline Temperature range $\left({ }^{\circ} \mathrm{C}\right)$ & $20-40$ & $25-50$ & $25-45$ & $25-45$ \\
\hline Temperature optimum $\left({ }^{\circ} \mathrm{C}\right)$ & $28-32$ & $30-37$ & $30-37$ & $30-37$ \\
\hline $\mathrm{pH}$ range & $5-8$ & $6-9$ & $6-8$ & $6-8$ \\
\hline $\mathrm{pH}$ optimum & $6-7$ & $7-7.5$ & $7-8$ & $7-8$ \\
\hline \multicolumn{5}{|l|}{$\begin{array}{l}\text { Menaquinone composition } \\
(\%)\end{array}$} \\
\hline MK-6 & - & 51.2 & - & - \\
\hline MK-7 & - & 13.5 & - & - \\
\hline MK-9 & 5.2 & - & 7.5 & - \\
\hline MK-9 $\left(\mathrm{H}_{2}\right)$ & 1.7 & 2.0 & 25.5 & 3.7 \\
\hline MK-9 $\left(\mathrm{H}_{4}\right)$ & 26.4 & 12.0 & 51.9 & 44.9 \\
\hline MK-10 $\left(\mathrm{H}_{4}\right)$ & 51.2 & 14.3 & 8.1 & 43.9 \\
\hline MK-10 $\left(\mathrm{H}_{6}\right)$ & 5.0 & - & 2.6 & 2.6 \\
\hline \multicolumn{5}{|l|}{ Phospholipid composition } \\
\hline PG & - & + & - & - \\
\hline PI & + & - & + & + \\
\hline PE & + & - & - & - \\
\hline PIM & - & - & + & + \\
\hline
\end{tabular}

Data for physiological tests were from this study, except those of A. xinjiangensis TRM $40136^{\mathrm{T}}$ (taken from Guan et al. 2010). Data for chemotaxonomical analyses were realized under the same conditions

+ Positive, - negative, $N D$ not determined, $P G$ phosphatidylglycerol, $P I$ phosphatidylinositol, $P E$ phosphatidylethanolamine, $P I M$ phosphatidylinositol mannoside. Strains: 1, A. righensis $\mathrm{H}_{2} 3^{\mathrm{T}}$; 2 , A. xinjiangensis TRM $40136^{\mathrm{T}}$; 3 , A. erythraea DSM $45583^{\mathrm{T}}$; 4, A. alba DSM $45004^{\mathrm{T}}$ type strain A. saharensis DSM $45459^{\mathrm{T}}$ exhibited $16 \mathrm{~S}$ rRNA gene sequence similarity values of 98.8 and $98.5 \%$ respectively with its nearest neighbours $A$. algeriensis DSM $45476^{\mathrm{T}}$ and A. halophila DSM $43834^{\mathrm{T}}$, however shared a DNA-DNA relatedness value of 30.5 and $55.1 \%$ (Meklat et al. 2013). The type strains A. algeriensis DSM $45476^{\mathrm{T}}$ and A. halophila DSM $43834^{\mathrm{T}}$ shared also a $16 \mathrm{~S}$ rRNA gene sequence similarity of $98.5 \%$, but had a DNA-DNA relatedness of only $24.7 \%$ (Meklat et al. 2012). Furthermore, the type strains of A. alba DSM $45004^{\mathrm{T}}$ and A. erythraea DSM $45583^{\mathrm{T}}$ with a $16 \mathrm{~S}$ rRNA similarity value of $97.6 \%$ shared a DNA-DNA relatedness value of $46.8 \%$ (Tang et al. 2011). In addition, Stackebrandt and Ebers (2006) recommend a 16S rRNA gene sequence similarity threshold range of 98.7-99.0\% as the point at which DNA-DNA reassociation experiments should be mandatory for testing the genomic uniqueness of novel isolates. Furthermore, MeierKolthoff et al. (2013) showed that the DNA-DNA hybridization should be mandatory only above a similarity percentage of $98.2 \%$ (based on 16S rRNA gene). For instance, the error probability is very insignificant $(0.025 \%)$ in a percentage of $97.8 \%$ (as in our case).

In addition, the strain $\mathrm{H} 23^{\mathrm{T}}$ differs from other closely related species of Actinopolyspora not only by physiological characteristics (utilization of fructose, galactose, lactose, maltose, mannitol, mannose, xylose, casein, starch and Tween 80), but also by chemotaxonomical characteristics. Indeed, the predominant menaquinones were MK-10 $\left(\mathrm{H}_{4}\right)$ and MK-9 $\left(\mathrm{H}_{4}\right)$ for $\mathrm{H} 23^{\mathrm{T}}$ and A. alba, MK-9 $\left(\mathrm{H}_{2}\right)$ and MK-9 $\left(\mathrm{H}_{4}\right)$ for A. erythraea, and MK-6 for A. xinjiangensis. Moreover, phosphatidylethanolamine was present only in $\mathrm{H} 23^{\mathrm{T}}$, while phosphatidylglycerol was present only in A. xinjiangensis. In addition, the strain $\mathrm{H} 23^{\mathrm{T}}$ differs from $A$. xinjiangensis by the presence of phosphatidylinositol, and from A. erythraea and $A$. alba by the presence of phosphatidylinositol mannoside.

On the basis of the phenotypic, chemotaxonomic and phylogenetic data presented, strain $\mathrm{H} 23^{\mathrm{T}}$ should be placed in the genus Actinopolyspora as the type strain of a novel species, for which we propose the name Actinopolyspora righensis sp. nov. 


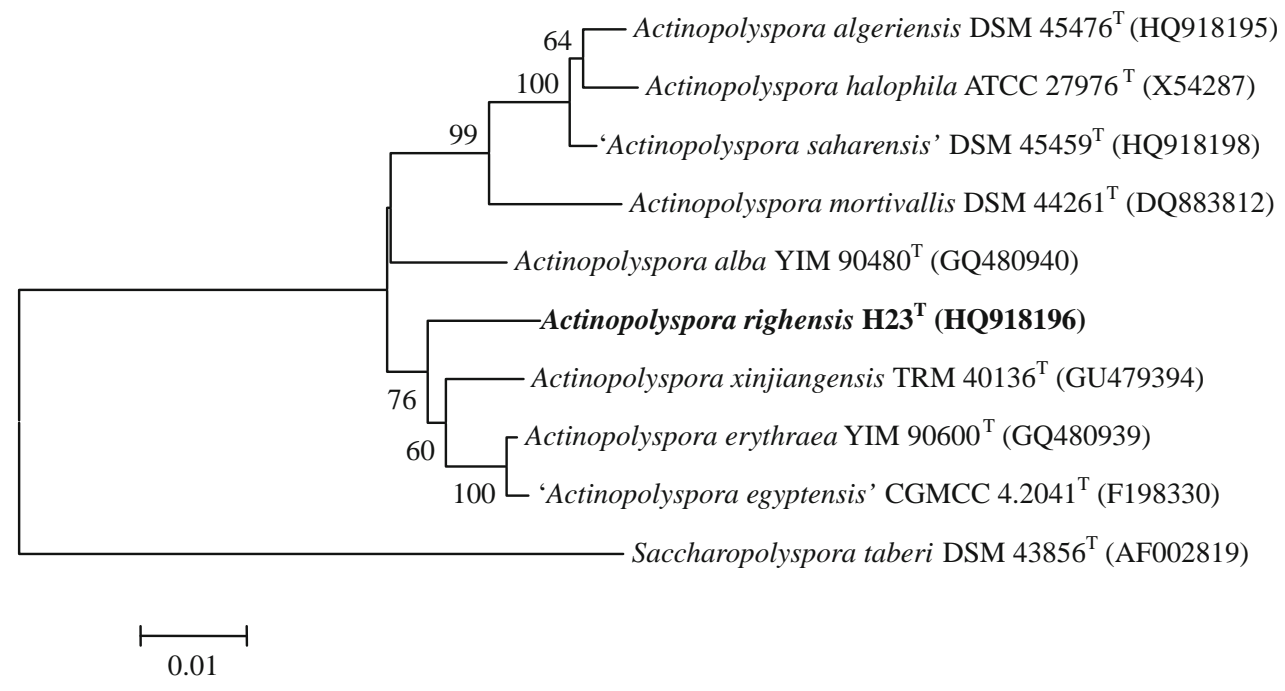

Fig. 2 Phylogenetic tree for species of the genus Actinopolyspora calculated from almost complete 16S rRNA gene sequences using Jukes and Cantor (1969) evolutionary distance methods and the neighbour-joining method of Saitou and Nei (1987). This illustrates the taxonomic position of strain $\mathrm{H} 23^{\mathrm{T}}$

\section{Description of Actinopolyspora righensis sp. nov.}

Actinopolyspora righensis (ri.ghen'sis, N.L. fem. adj. righensis pertaining to Oued Righ, where the type strain was isolated).

Gram-positive, extremely halophilic, filamentous, aerobic actinomycete; forms white aerial mycelium and yellow substrate mycelium. Good growth occurs on $\mathrm{CM}$ agar and nutrient agar media. Diffusible pigments are not produced. Substrate hyphae are well developed and fragment with age. Long, straight or flexuous spore chains are borne on aerial hyphae, which fragment into rod-shaped non-motile spores $(0.5-0.6 \times 1.2-1.8 \mu \mathrm{m})$ with smooth surfaces. Grows optimally at $28-32{ }^{\circ} \mathrm{C}$ and pH 6-8 and in the presence of $15-25 \%(w / v) ~ N a C l$. Growth is not observed in the absence of $\mathrm{NaCl}$. Able to reduce nitrate to nitrite. Degrades adenine, casein, gelatin, guanine, hypoxantine, Tween 80 and tyrosine, but not starch, testosterone or xanthine. The following compounds are utilized: adonitol, arabinose, glucose, glycerol, cellobiose, erythritol, fructose, galactose, lactose, maltose, mannose, melezitose, rhamnose, ribose, sorbitol, sucrose, xylose and proline. The following substances are not utilized: mannitol, melibiose, raffinose, salicin, trehalose, alanine and serine. Acetate, citrate and pyruvate are decarboxylated but not, benzoate, butyrate, oxalate, propionate, succinate and tartrate. Milk was coagulated and peptonized. $\mathrm{H}_{2} \mathrm{~S}$ was not relative to the other species of the genus. Numbers at the nodes are bootstrap values, expressed as a percentage of 1,000 resamplings (only values $>50 \%$ are shown). Bar 0.01 nucleotide substitution per site

produced. Methyl red and Voges-Proskauer tests were negative. Resistant to kanamycin $\left(5 \mu \mathrm{g} \mathrm{ml}^{-1}\right)$, erythromycin $\left(10 \mu \mathrm{g} \mathrm{ml}^{-1}\right)$, streptomycin $\left(10 \mu \mathrm{g} \mathrm{ml}^{-1}\right)$, penicillin $\left(25 \mu \mathrm{g} \mathrm{ml}^{-1}\right)$, and lysozyme $(0.005 \% \mathrm{w} / \mathrm{v})$, but susceptible to chloramphenicol $\left(25 \mu \mathrm{g} \mathrm{ml}^{-1}\right)$. Contains meso-diaminopimelic acid, as cell-wall diamino acid, and arabinose and galactose as major whole-cell sugars. The diagnostic phospholipid is phosphatidylcholine. The major fatty acids are anteiso- $\mathrm{C}_{17: 0}(37.4 \%)$, iso- $\mathrm{C}_{17: 0}$ $(14.8 \%)$, iso- $\mathrm{C}_{15: 0}(14.2 \%)$, and iso- $\mathrm{C}_{16: 0}(13.9 \%)$. MK-10 $\left(\mathrm{H}_{4}\right)$ and MK-9 $\left(\mathrm{H}_{4}\right)$ are the predominant menaquinones. Mycolic acids are not detected.

The type strain is $\mathrm{H} 23^{\mathrm{T}}\left(=\mathrm{DSM} 45501^{\mathrm{T}}=\mathrm{CCUG}\right.$ $63368^{\mathrm{T}}=$ MTCC $11562^{\mathrm{T}}$ ) isolated from a Saharan soil sample collected from Oued Righ region (South Algeria). The 16S rRNA gene sequence of strain $\mathrm{H} 23^{\mathrm{T}}$ has been deposited in GenBank under the accession number HQ918196.

Acknowledgments The authors are grateful to Mohand Amokrane Meklat for providing soil sample from Oued Righ, Gabriele Pötter (DSMZ) for growing A. righensis cultures and for assistance with chemotaxonomical analyses.

\section{References}

Becker B, Lechevalier MP, Gordon RE, Lechevalier HA (1964) Rapid differentiation between Nocardia and Streptomyces 
by paper chromatography of whole-cell hydrolysates. J Appl Microbiol 12:421-423

Chun J, Bae KS, Moon EY, Jung SO, Lee HK, Kim SJ (2000) Nocardiopsis kunsanensis sp. nov., a moderately halophilic actinomycete isolated from a saltern. Int J Syst Evol Microbiol 50:1909-1913

Felsenstein J (1981) Evolutionary trees from DNA sequences: a maximum likelihood approach. J Mol Evol 17:368-376

Felsenstein J (1985) Confidence limits on phylogenies: an approach using the bootstrap. Evolution 39:783-791

Fitch WM (1977) On the problem of discovering the most parsimonious tree. Am Nat 111:223-257

Gochnauer MB, Leppard GG, Komaratat P, Kates M, Novitsky T, Kushner DJ (1975) Isolation and characterization of Actinopolyspora halophila, gen. et sp. nov., an extremely halophilic actinomycete. Can J Microbiol 2:150-1511

Gochnauer MB, Johnson KG, Kushner DJ (1989) Genus Actinopolyspora. In: Williams ST, Sharpe ME, Holt JG (eds) Bergey's manual of systematic bacteriology, vol 4. Williams \& Wilkins, Baltimore, pp 2398-2401

Goodfellow M (1971) Numerical taxonomy of some nocardioform bacteria. J Gen Microbiol 69:33-90

Gordon RE, Barnett DA (1977) Resistance to rifampicin and lysozyme of strains of some species of Mycobacterium and Nocardia as a taxonomic tool. Int $\mathbf{J}$ Syst Bacteriol 27:176-178

Gordon RE, Barnett DA, Handerhan JE, Pang CHN (1974) Nocardia coeliaca, Nocardia autotrophica, and the nocardin strain. Int J Syst Bacteriol 24:54-63

Guan TW, Liu Y, Zhao K, Xia ZF, Zhang XP, Zhang LL (2010) Actinopolyspora xinjiangensis sp. nov., a novel extremely halophilic actinomycete isolated from a salt lake in Xinjiang, China. Antonie Van Leeuwenhoek 98:447-453

Hozzein WN, Goodfellow M (2011) Actinopolyspora egyptensis sp. nov., a new halophilic actinomycete. Afr J Microbiol Res 5:100-105

Jukes TH, Cantor CR (1969) Evolution of protein molecules. In: Munro HN (ed) Mammalian protein metabolism, vol 3. Academic Press, New York, pp 21-132

Kelly, KL, Judd DB (1976) Color. Universal language and dictionary of names (National Bureau of Standards special publication 440). US Department of Commerce, Washington

Kim OS, Cho YJ, Lee K, Yoon SH, Kim M, Na H, Park SC, Jeon YS, Lee JH, Yi H, Won S, Chun J (2012) Introducing EzTaxon-e: a prokaryotic 16S rRNA gene sequence database with phylotypes that represent uncultured species. Int J Syst Evol Microbiol 62:716-721

Kimura M (1980) A simple method for estimating evolutionary rates of base substitutions through comparative studies of nucleotide sequences. J Mol Evol 16:111-120

Kroppenstedt RM (1982) Separation of bacterial menaquinones by HPLC using reverse phase (RP18) and a silver loaded ion exchanger as stationary phases. J Liq Chromatogr 5:2359-2367

Kroppenstedt RM (1985) Fatty acid and menaquinone analysis of actinomycetes and related organisms. In: Goodfellow M, Minnikin DE (eds) Chemical methods in bacterial systematics. Academic Press, London, pp 173-179

Larkin MA, Blackshields G, Brown NP, Chenna R, McGettigan PA, McWilliam H, Valentin F, Wallace IM, Wilm A, Lopez R, Thompson JD, Gibson TJ, Higgins DG (2007)
Clustal W and Clustal $\mathrm{X}$ version 2. Bioinformatics 23:2947-2948

Lechevalier MP, Lechevalier HA (1970) Chemical composition as a criterion in the classification of aerobic actinomycetes. Int J Syst Bacteriol 34:435-444

Lechevalier MP, Bièvre C, Lechevalier HA (1977) Chemotaxonomy of aerobic actinomycetes: phospholipid composition. Biochem Syst Ecol 5:249-260

Liu D, Coloe S, Baird R, Pedersen J (2000) Rapid mini-preparation of fungal DNA for PCR. J Clin Microbiol 38:471

Marchal N, Bourdon JL, Richard CL (1987) Les milieux de culture pour l'isolement et l'identification biochimique des bactéries. Doin Press, Paris

Meier-Kolthoff JP, Göker M, Spröer C, Klenk HP (2013) When should a DDH experiment be mandatory in microbial taxonomy? Arch Microbiol 195:413-418

Meklat A, Sabaou N, Zitouni A, Mathieu F, Lebrihi A (2011) Halophilic actinomycetes in Saharan soils of Algeria: isolation, taxonomy and antagonistic properties. Appl Environ Microbiol 77:6710-6714

Meklat A, Bouras N, Zitouni A, Mathieu F, Lebrihi A, Schumann P, Spröer C, Klenk HP, Sabaou N (2012) Actinopolyspora algeriensis sp. nov., a novel halophilic actinomycete isolated from a Saharan soil. Extremophiles $16: 771-776$

Meklat A, Bouras N, Zitouni A, Mathieu F, Lebrihi A, Schumann P, Spröer C, Klenk HP, Sabaou N (2013) Actinopolyspora saharensis sp. nov., a novel halophilic actinomycete isolated from a Saharan soil of Algeria. Antonie Van Leeuwenhoek 103:771-776

Minnikin DE, Patel PV, Alshamaony L, Goodfellow M (1977) Polar lipid composition in the classification of Nocardia and related bacteria. Int J Syst Bacteriol 27:104-117

Minnikin DE, Hutchinson IG, Caldicott AB, Goodfellow M (1980) Thin layer chromatography of methanolysates of mycolic acid-containing bacteria. J Chromatogr A 188:221-233

Minnikin DE, O'Donnell AG, Goodfellow M, Alderson G, Athalye M, Schaal A, Parlett JH (1984) An integrated procedure for the extraction of isoprenoid quinones and polar lipids. J Microbiol Methods 2:233-241

Rainey FA, Ward-Rainey N, Kroppenstedt RM, Stackebrandt E (1996) The genus Nocardiopsis represents a phylogenetically coherent taxon and a distinct actinomycete lineage: proposal of Nocardiopsaceae fam. nov. Int J Syst Bacteriol 46:1088-1092

Saitou N, Nei M (1987) The neighbor-joining method: a new method for reconstructing phylogenetic trees. Mol Biol Evol 4:406-425

Sasser M (1990) Identification of bacteria by gas chromatography of cellular fatty acids, technical note 101 . Microbial ID, Newark

Shirling EB, Gottlieb D (1966) Methods for characterization of Streptomyces species. Int J Syst Bacteriol 16:313-340

Stackebrandt E, Ebers J (2006) Taxonomic parameters revisited: tarnished gold standards. Microbiol Today 33:152-155

Tang SK, Wang Y, Klenk HP, Shi R, Lou K, Zhang YJ, Chen C, Ruan JS, Li WJ (2011) Actinopolyspora alba sp. nov. and Actinopolyspora erythraea sp. nov., isolated from a salt field, and reclassification of Actinopolyspora iraqiensis Ruan et al. 1994 as a heterotypic synonym of 
Saccharomonospora halophila. Int J Syst Evol Microbiol 61:1693-1698

Waksman SA (1961) Classification, identification, and descriptions of genera and species. In: The actinomycetes, vol 2. Williams \& Wilkins, Baltimore, pp 331-332

Wayne LG, Brenner DJ, Colwell RR, Grimont PAD, Kandler O, Krichevsky MI, Moore LH, Moore WEC, Murray RGE, Stackebrandt E, Starr MP, Trüper HG (1987) International committee on systematic bacteriology. Report of the ad hoc committee on the reconciliation of approaches to bacterial systematic. Int J Syst Bacteriol 37:463-464
Yoshida M, Matsubara K, Kudo T, Horikoshi K (1991) Actinopolyspora mortivallis sp. nov., a moderately halophilic actinomycete. Int J Syst Bacteriol 41:15-20

Zhi XY, Li WJ, Stackebrandt E (2009) An update of the structure and 16S rRNA gene sequence-based definition of higher ranks of the class Actinobacteria, with the proposal of two new suborders and four new families and emended descriptions of the existing higher taxa. Int J Syst Evol Microbiol 59:589-608 